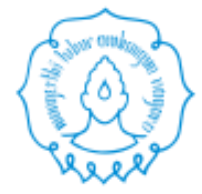

UNIVERSITAS SEBELAS MARET

BIOEDUKASI: JURNAL PENDIDIKAN BIOLOGI

https://jurnal.uns.ac.id/bioedukasi/

1693-265X (Print) | 2549-0605 (Online)

\title{
Profile of Science Literacy of Grade 10 Students Using Computer- Supported Collaborative Learning (CSCL) Model
}

\author{
Wita Wulan Januaresty ${ }^{1}{ }^{*}$, Sistiana Windyariani, Jujun Ratnasari \\ aBiology Education of Universitas Muhammadiyah Sukabumi, Sukabumi-Indonesia \\ 1 witajanuary23@gmail.com * \\ * Corresponding author
}

$\begin{array}{ll}\text { Submission } & : 27 / 05 / 2021 \\ \text { Revision } & : 07 / 08 / 2021 \\ \text { Accepted } & : 31 / 08 / 2021\end{array}$

\section{ABSTRACT}

This study aims to determine the effect of the CSCL model on science literacy (SL). SL is considered as the abilities to use science knowledge to solve the science problem by utilizing the critical thinking skills. The quasi-experimental with a non-equivalent group design was applied as the research method. Subjects of this research were grade 10 students $(\mathrm{N}=50)$. Different tests were carried out to determine the existence of science literacy. There are 3 aspects of knowledge assessed in SL skills, i.e., content, procedural, and epistemic knowledge. The instruments used was a 15 questions of science literacy consisting of 5 content knowledge, 5 procedural, 5 epistemic questions, and an assessment of interest in SL. The results showed the average of content knowledge of experimental class was 76.92\% or in a high category, and control class was $73.33 \%$ or in moderate category. The average of procedural knowledge of the experimental class was $66.92 \%$ and the control class was $64.99 \%$, or both were moderate. And the average of epistemic knowledge of the experimental class was $64.61 \%$ and the control class was $60.99 \%$ or both moderate. The assessment of attitudes towards SL aims to give an idea that students have an interest in the components of SL attitudes.

This is an open-access article under the CC-BY-SA license
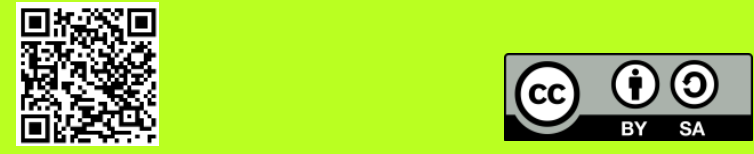

Keywords: scientific literacy skills, content knowledge, procedural knowledge and epistemic knowledge 



\section{Introduction}

The changes of curriculum has lead to be adjusted with the demand of $21^{\text {st }}$ Century Competencies. In 2013 Curriculum, the learning process must follow the scientific learning, in which students are put into a condition where they can improve their critical thinking skill and problem solving skills, creativity and innovation, collaboration, and communication (Redhana, 2019).

Science is a sequence of knowledge related to natural phenomena and learned from researchers' inventions produced by trials through scientific method so that it is necessary to apply science literacy for the students. Science literacy is defined by Programme for International Students Assessment (PISA) as knowledge and the use of it in identifying questions, acquiring new knowledge, explaining scientific phenomenon and establishing conclusion based on evidences (Nugraheni et al., 2019). The 21 ${ }^{\text {st }}$ education vision are based on learning paradigm is logical knowledge-oriented thinking learning, problem-solving oriented learning, self-character-building oriented learning, as well as tolerant and cooperative oriented learning. Those learning orientation aim to improve the scientific literacy by applying science learning that focuses on attitude, ideas, scientific process skills and emphasized in scientific inquiry activities. If the learnings mentioned are applied, thus it is believed that it can improve students' enthusiasm, motivation, curiosity, and admiration upon science (Yuliati, 2017).

This issue has been a challenge in the advance of technology especially regarding learning activities that are expected to be able to improve thinking ability and to face the $21^{\text {st }}$ century challenges that require the students to be able to think critically, solve the problem systematically, cooperate with each other, appreciate others' arguments, and be able to communicate scientifically (Wulandari \& Wulandari, 2016).

The advanced of technology and knowledge has brought great influence to the improvement of the education in Indonesia. Along with the advanced of information technology, the development of education has been changed to a better state. The students in the next generations must be prepared for the challenges in the era of globalization. The students are required to be able to construct information like logical, critical, creative and innovative knowledge as well as analyse and adapt to surrounding natural phenomena as learning materials and apply them in daily contextual cases (Hasasiyah et al., 2019).

Educational process has shown a rapid development in curriculum, learning methods, and supporting facilities. The rapid development of science and technology in the $21^{\text {st }}$ century requires humankind to work harder and smarter to adapt in every sector in daily life. One of the keys to succeed in facing the $21^{\text {st }}$ century challenge is by having science literacy since a person who has science literacy can use his/her scientific information to solve problems in daily life as well as produce useful scientific products. Science education has an essential role in preparing an individual student to be involved in his future life (Nofiana, 2017). Designing and evaluating scientific investigations competence shows the highest affectivity score, which in a sequence is followed by explaining phenomenon scientifically afterwards interpreting data and evidences scientifically (Setiawan, 2019). Competencies will not be achieved unless the students are able to apply scientific process and analyse phenomena, understand the need of hard work in a process, as well as be responsible in constructing the problems and establishing conclusion. Learning process that emphasizes actions during the process is a learning that focuses on students' participation or successful learning comes from doing and creates attitudes that go along with good morals.

Science literacy is from the Latin literatus which means educated, and scientia which means knowledge. The connection between those two words is that science literacy is an ability to utilise scientific knowledge, identify questions and describe evidences based on 
conclusion regarding science and technology in daily life. Science literacy is an essential thing for individual as an individual as well as part of a social community. In this case, literacy is not only helping the individuals to learn, improve, and interact with other individuals, but also preparing each of them to fulfil his/her own needs in facing the $21^{\text {st }}$ century challenges (Zakaria \& Rosdiana, 2018).

Improving SL needs to be prepared for the students in order to solve problems regarding daily life. Every individual is required to possess science literacy skill, this has connection to how an individual can understand problems in his/her living environment as well as other problems faced by the modern society that relays a lot in science and technology (Haerani et al., 2020). Rahayu (2017) explains that SL focuses on the importance of language mastery, proper reading and writing in understanding and explaining phenomena, evaluating information, communicating ideas to other people, implementing scientific knowledge and logical thinking regarding daily life's cases, as well as decision making process of the students in content knowledge depending on students' abilities in screening and keeping the information achieved. SL has a relatively long history and mostly used in a wide scope in science education in various education level (Naila \& Khasna, 2021).

Understanding of high scientific knowledge (content knowledge) provides the students to be able to utilise procedural knowledge since the prior-knowledge about ideas and essential characteristics explanation towards knowledge construction in science as well as its contribution in proving the truth of knowledge generated by science has been achieved. The transfer of knowledge to the students depends on the main information network and the filter through their perspective based on their skills and passion (Nalimun, 2017). Science literacy consists of several levels, the lowest level of science literacy is called practical science or functional science that refers to a person's ability to survive in his/her daily life, as a consumer of science products and technologies that leads to human basic needs such as food health and houses. A high science literacy level is like a citizenship literacy based on a person's ability to participate in a decision making and use it wisely regarding politics, economy, social, cultural, and matters pertaining to the state (Narut \& Supardi, 2019).

Data of Programme for International Student Assessment-Organisation for Economic Cooperation and Development (PISA-OECD) in 2012 shows that SL skills of students in Indonesia is still categorized as low. Nofiana \& Julianto, Teguh (2017) states that "PISA-OECD has been possible to monitor Indonesian students' SL skills. Since 2000 - 2012, the achievement of students in Indonesia has shown a degression. In 2009, Indonesia was in rank 60 out of 65 countries. In 2012, the rank was sinking from 60 to 64 out of 65 countries. In 2016, out of 70 countries, Indonesia was still in rank $62^{\text {nd" }}$. The result of the research conducted by PISA shows that students in Indonesia still need more development strategies for the students to learn. Science literacy as an implementation of knowledge for the students is essential in order to improve critical thinking skills and face the $21^{\text {st }}$ century challenges. There are 3 knowledge aspects identified in science literacy skill which are content knowledge, procedural knowledge, and epistemic knowledge, explained as follow: a) content knowledge is a knowledge relevant to real life cases; b) procedural knowledge is a knowledge that explores knowledge in form of identifications of experiment variables; c) epistemic knowledge is a knowledge regarding identification of scientific aspect, data justification, as well as scientific arguments (Rini et al, 2021).

SL score of Indonesia students shows the Indonesian students' SL is still low. The objective of SL that is expected to be achieved by the students is in the science subjects, including but not limited to Biology since in Biology there are several numbers of phenomena that happen in daily life. One of Biology's subject materials that can provide science literacy learning is material about fungi. 
Specifically, science is understood as a natural science because it is a science that studies about the nature and the interactions of creature and its surrounding (Muhammad \& Adhani, 2018). In developing SL, an educator focuses to increase the students' understanding in 1) knowledge and investigation of natural science, 2) verbal and textual vocabularies required to understand and communicate knowledge and 3) the connection between science, technology, and society (Pertiwi et al., 2018)

Computer-Supported Collaborative Learning (CSCL) is a collaborative learning model supported by computer where the students are in a computer network to optimize individuals, teams, and the learning output to achieve learning objectives through discussions and helpful supports. This learning model consist of various technologies meant to facilitate, share and distribute lessons and learnings, especially regarding CSCL, as multimedia, experimental simulation, and implemented program, all of them work simultaneously in supporting the collaboration among the students (Allaymoun, 2018). Dascalu et al., (2018) states that "in every context, plan modelled from perspectives as interactions with others, basically towards building meaning and understanding". The appearance of ideology framework focusing on the five sense, according to Linell, "there are three interaction perspectives with others, which are: 1) Action, action done in interacting meaningfully in a context, 2) Cognition, cognition achieved about the world and determining meaning through language and interaction with others in a determined context, and 3) Communication, interaction with others generates meaning of discourse and also combining strong cognitive components" (in Dascalu et al., 2018).

Fungi learning material covers about phenomena happened in daily life so that it can attract and also generate curiosity of the students regarding the phenomena that affect the students directly. This will lead to the students' decision making towards scientific evidences found by themselves. The connection between science learning and science literacy can be seen in two steps, which are: (1) science learning explains science literacy that is stated generally (2) science learning increases the science's value itself (Situmorang, 2016). Science literacy's perspective towards the importance of learning skill and actions involved thinking mastery as well as using scientific thinking in reacting to social issues, understanding the environment, health, economy, modern social, and technology (Pratiwi et al., 2019). In the meantime, Islamic boarding schools are commonly known by the society where the students come from different cities with their character diversity. Students are placed in a 24-hour Islamic environment including school and religious activities. This issue distinguishes the Islamic boarding school with conventional public or private schools. Moreover, the curriculum used in MA. Assalam Darul Faizah is curriculum based on religion ministry and Gontor so that the lessons taught are more than the lessons taught in conventional schools. The interesting part in Islamic Boarding Schools is the fact that most of the lessons are taught in Arabic or English. This obviously attracts the curiosity of an educator to evaluate the students' ability in science. Students in the Islamic boarding school environment have more attention in actualizing science literacy by taking advantage of the proper school internet facility, mostly Islamic boarding schools limit the use of gadgets during the learning and teaching activities as well as lessons taught in English or Arabic. This issue is worth researching because the students in an Islamic boarding school need to improve their skill in science literacy. Developing science literacy in daily learning is essential to improve the scientific attitudes and master the science literacy. Science literacy helps us to understand further regarding natural phenomena or phenomena caused by humans related to the concepts given to the students at school. The students are expected to be able to explain scientific phenomena, evaluate and design scientific research as well as provide interpretation of data, and improve the scientific evidences (Adawuyah \&Wisudawati, 2017). 
Based on the statements above, the researcher aims to analyze the literacy science skill of students towards the aspects of the X grade students' PISA science literacy in Fungi learning material. The low science literacy skill in Indonesia is described by Nofiana \& Julianto (2017) in their statement, as follow: "PISA-OECD has done monitoring regarding the students' science literacy level. Since 2000-2012, the achievement of Indonesian students suffers a degradation. In 2009, Indonesia is in rank 60 out of 65 countries. In 2012, the rank is sinking from 60 to 64 out of 65 countries. In 2016, out of 70 countries, Indonesia is still in rank $62^{\text {nd" }}$. Thus, it is indeed a concern that needs to be paid attention to that the students must be able to possess $21^{\text {st }}$ century skills as a fundamental in competing especially in technology and information sector by taking advantage of the internet facility provided at school in order to avoid the limitation of the students in communication, information and technology even if the students are limited due to the Islamic boarding schools' rules that limit the students in using their gadgets. Biology learning conducted outside the class by utilizing the computer laboratory as a media to improve information references and observation becomes new activities conducted by researched school.

\section{Methods}

The research time in odd semester starts from September to January 2021. Type of research is development research, Research and Development (R\&D) with ADDIE model developed by Dick and Carey (2005). ADDIE model consists of stages namely analyze, design, development, implementation and evaluate. But in this study only reached the stage of development (development). As for the implementation and evaluate stage is carried out in the next research.

The research method used is quasi experimental design which is defined as an experiment that has treatment, measurement of impact, to create comparisons in order to conclude changes caused by treatment.

\section{Population and Sample}

The population used in the study were MA Assalam Darul Faizah Warungkiara, Sukabumi students. Grade 10 for the academic year 2020-2021 which consists of two classes with a total of 50 students from each experimental class with 26 people and 24 students of control class. In the experimental class, treatment is given in the form of a CSCL (ComputerSupported Collaborative Learning) model that utilizes a computer as a medium. Support in learning while in the control class the learning treatment is in the form of conventional learning, namely discussion. The sample data of this study were taken from data sources from the class that was used as the respondent at the time of the research, namely class $\mathrm{X}$ semester 2 with the same level of ability.

\section{Research Instrument}

The instrument used in the form of scientific literacy questions consisting of 15 questions including 5 content knowledge questions, 5 procedural knowledge questions and 5 epistemic knowledge questions, these three types have questions that are related to the illustrations presented and the instrument for assessing the attitude of interest in scientific literacy in each illustration of scientific literacy questions which includes three components of scientific literacy readiness, namely: interest in science, assessing scientific approaches to investigation and environmental awareness.

\section{Data Collection Method}

Data collection was carried out through post-test questions in the form of scientific literacy questions which included discussion material on fungi/fungi. This is done to 
determine the initial ability to master the material. The data obtained were designed using a frequency table on the achievement of learning outcomes expressed in the form of numbers.

\section{Data Analysis Method}

This analysis method uses SPSS software to evaluate the validity and reliability of the data by interpreting using criteria below:

1. Validity Test

Researcher used SPPS software for testing the validity of the data. The method used is correlation Bivariate Pearson. This analysis is done by correlating each item's score with the items' total score. If $r_{\text {count }} \geq r_{\text {table }}$ (2-sided test with sig. 0,05), thus the instrument or the question items are correlating significantly towards the total score (stated as valid). Fifteen exercises got significant score of 0,444

Thus, the instrument is stated as valid. The formula for correlation is shown below

$$
r_{x y}=\frac{N \Sigma x y-(\Sigma x)(\Sigma y)}{\sqrt{\left(N \Sigma x^{2}\right.}-(\Sigma x)^{2}\left(N \Sigma y^{2}-(\Sigma y)^{2}\right.}
$$

$r_{x y}=$ Correlation Coefficient between $\mathrm{X}$ and $\mathrm{Y}$

$\Sigma x y=$ The sum of the result of multiplication of variable $X$ and variable $Y$

$(\Sigma x)^{2} \quad=$ The sum of the square of $X$

$(\Sigma y)^{2} \quad=$ The sum of the square of $Y$

\section{Reliability Test}

The reliability shows that the instrument. During my life time, reliability indicates whether a research instrument is reliable or not as a data collecting instrument. The level of the reliability is shown empirically by a number called reliability coefficient. Reliability testing using Alpha Croncbach formula, as follow:

$$
r_{11}=\left(\begin{array}{c}
n \\
n-1
\end{array}\right)\left(1-\frac{\Sigma \sigma 2 t}{\sigma 2 t}\right)
$$

Decription:

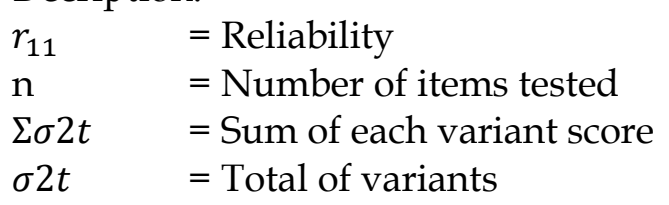

Based on the Cronbach's Alpha reliability test result achieved is 0,860 which shows that this reliability test is reliable. $\mathrm{N}$ of item is 15 .

\section{Literacy Science Score}

Calculating the literacy science score by giving score 1 score for correct answer and 0 score for wrong incorrect answer. Every sample is calculated with the following formula (Purwanto, 2009):

$$
\mathrm{NP}=\mathrm{R} / \mathrm{SM} \times 100 \%
$$

NP : Percentage Score (Score Expected to be achieved).

R : Achieved Score

SM : Maximum score of the ideal test 
100 : constant.

Tabel 3. Literacy Science Category Percentage

\begin{tabular}{cc}
\hline Percentage & Category \\
\hline $80 \%-100 \%$ & Very High \\
\hline $76 \%-85 \%$ & High \\
\hline $60 \%-75 \%$ & Medium \\
\hline $55 \%-59 \%$ & Low \\
\hline$\leq 54 \%$ & Very Low \\
\hline
\end{tabular}

Source: (Purwanto, 2009).

4. Statistic Difference Test (T-test)

T-test paired sample test is a difference test of 2 paired samples based on average. By making a hypothesis as follow:

$\mathrm{HO}=$ There is no difference in the learning output average of the students between the experimental and the control class

$\mathrm{H} 1$ = There is difference in the learning output average of the students between the experimental and the control class

The result of the test showed that paired differences in the mean of the pre-test scores is 29.220 with significant score of 0.000 . Meanwhile in the post-test the mean is 86.00 which significance score of 0.000 . Based on the interpretation result, it is found that the significance score is $<0.05$ so that the hypothesis can be accepted which means $\mathrm{H} 1=$ there is a difference in the learning output average of the students between experimental and the control class.

\section{Result and Discussion}

The analysis result of the data achieved by the experimental class and the control class students towards science literacy on each indicator given code for content knowledge $(\mathrm{K})$, procedural knowledge $(\mathrm{P})$ and epistemic knowledge $(\mathrm{E})$. The following below is the diagram of the research's result:

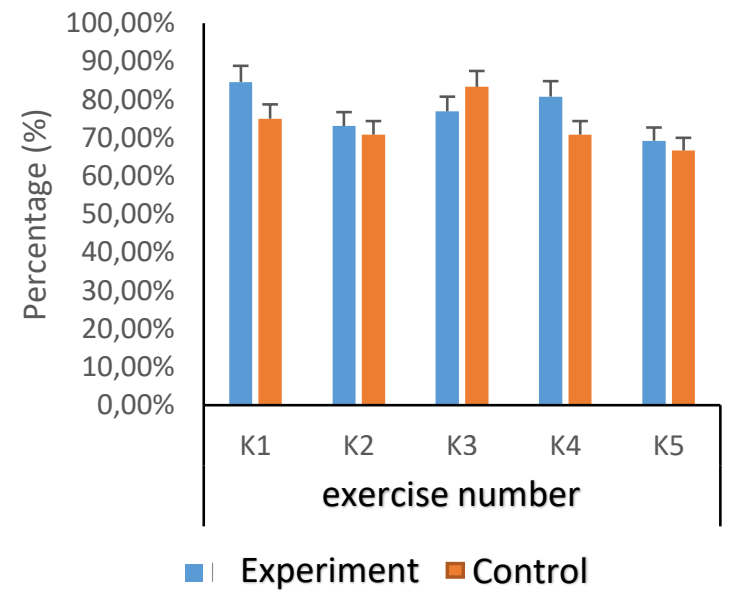

FIGURE 1. Content Knowledge

Based on figure 1, the highest post-test score is shown in Content 1 (K1) with $84.61 \%$ and deviation standard deviation of 0.367 , the exercises in content 4 (K4) achieved score $80,79 \%$ and standard deviation of 0.401 , the exercises in content 3 (K3) achieved with $76,92 \%$ percentage with standard deviation of 0.429 so that it's categorized high. The exercises in 
content 2 (K2) achieved score with 73.03\% percentage with standard deviation of 0.452 and the exercises in content 5 (K5) with score of $69.23 \%$ percentage and standard deviation 0.470 with category medium.

The highest score of the control class post-test is in content 3 (K3) achieved the score of $83.33 \%$ with standard deviation of 0.380 and categorized as high. The exercises of content 1 (K1) achieved score with percentage pf $75.00 \%$ and standard deviation of 0,442 . The exercises in content 2 (K2) and exercises in content $4(\mathrm{~K} 4)$ achieved with the percentage of $70.83 \%$ and standard deviation of $70.83 \%$ and standard deviation 0.464 and the exercises in content 5 (K5) achieved $66.66 \%$ percentage with 0.481 standard deviation, so that they are categorized as medium.

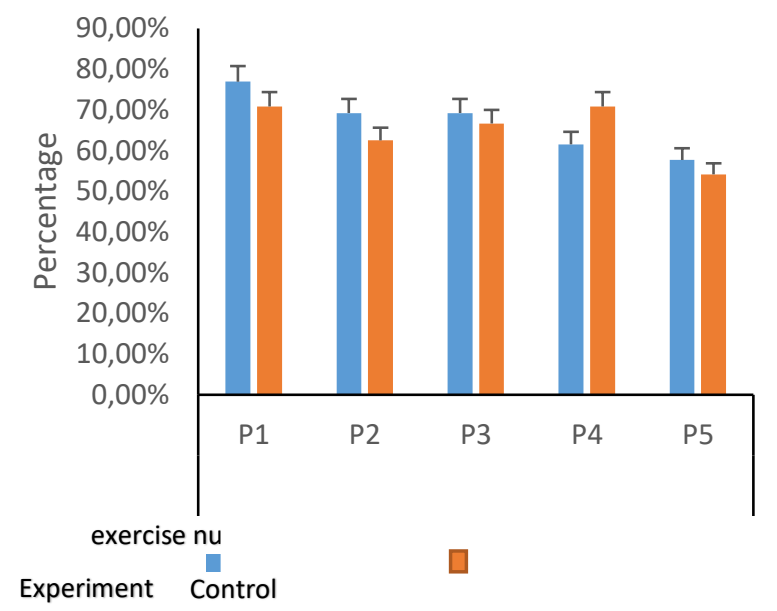

FIGURE 2. Procedural Knowledge

Based on Figure 2 the post-test value of the experimental class, the highest score on procedural question 1 (P1) obtained a percentage of $76.92 \%$ with a standard deviation of 0.429 , on procedural questions 2 (P2) and procedural 3 (P3) obtained a percentage of $69.23 \%$ with a standard deviation of 0.470 , on procedural question 4 (P4) obtained a percentage of 0.496 so that it was categorized as moderate and the smallest score on procedural question 5 (P5) obtained a percentage of $57.69 \%$ with a standard deviation of 0.503 which was categorized as less.

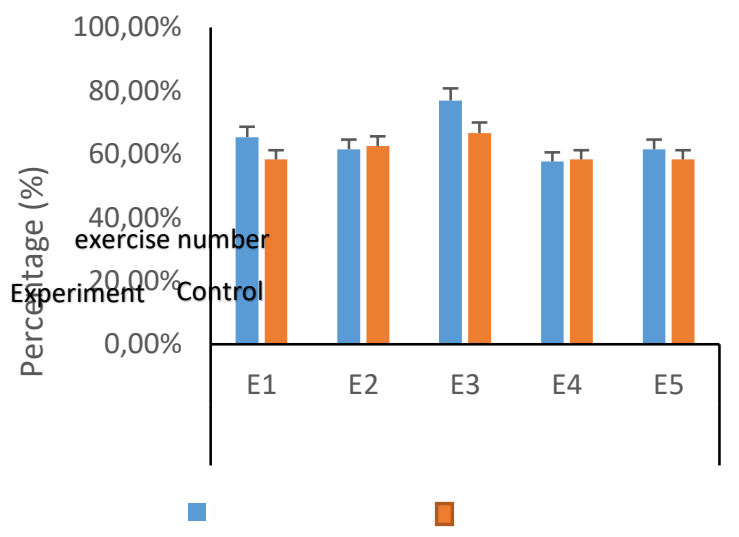

FIGURE 3. Epistemics Knowledge

The post-test value of the control class with the highest score, namely procedural 1 (P1) and procedural $4(\mathrm{P} 4)$ obtained a percentage of $70.83 \%$ with a standard deviation of 0.464 , on procedural questions 3 (P3) obtained a percentage of $66.66 \%$ with a standard deviation of 
0.481 , on the question procedural 2 (P2) obtained a percentage of 62.5 with a standard deviation of 0.494 and the lowest score on procedural question 5 obtained a percentage of $54.16 \%$ with a standard deviation of 0.508 and categorized very low.

Figure 3 displays about the post-test value of the experimental class, the highest score on epistemic questions 3 (E3) obtained a percentage of $76.92 \%$ with a standard deviation of 0.429 with a high category, epistemic item 1 (E1) obtained a percentage of $65.38 \%$ with a standard deviation of 0.485 , on epistemic questions 2 (E2) and epistemic questions 5 (E5) obtained a percentage of $61.53 \%$ with a standard deviation of 0.496 in the medium category. The lowest score on epistemic question 4 (E4) obtained a percentage of $57.69 \%$ with a standard deviation of 0.503 in the low category.

The control class score on epistemic questions 3 (E3) obtained a percentage of $66.66 \%$ with a standard deviation of 0.481 and on epistemic questions 2 (E2) obtained a percentage of $62.5 \%$ with a standard deviation of 0.494 in the medium category. As for epistemic questions 1 (E1), epistemic questions 4 (E4) and epistemic questions 5 (E5), the percentage is $58.33 \%$ with a standard deviation of 0.503 in the low category.

The average post-test results of the experimental and control classes on each scientific literacy indicator:

Table 4. The Results Average Content Knowledge Score

\begin{tabular}{ccc}
\hline & $\begin{array}{c}\text { Posttest } \\
\text { (Experiment) }\end{array}$ & $\begin{array}{c}\text { Posttest } \\
\text { (Control) }\end{array}$ \\
\hline Average & $76,92 \%$ & $73,33 \%$ \\
SD & 0,424 & 0,446 \\
Category & High & Medium \\
\hline
\end{tabular}

Table 5. Average Results of Procedural Knowledge Score

\begin{tabular}{ccc}
\hline & $\begin{array}{c}\text { Posttest } \\
\text { (Experiment) }\end{array}$ & $\begin{array}{c}\text { Posstest } \\
\text { (Control) }\end{array}$ \\
\hline Average & $66,92 \%$ & $64,99 \%$ \\
SD & 0,474 & 0,482 \\
Category & Medium & Medium \\
\hline
\end{tabular}

Table 6. Results Average Epistemic Knowledge Score

\begin{tabular}{ccc}
\hline & $\begin{array}{c}\text { Posttest } \\
\text { (Experiment) }\end{array}$ & $\begin{array}{c}\text { Posstest } \\
\text { (Control) }\end{array}$ \\
\hline Average & $64,61 \%$ & $60,83 \%$ \\
SD & 0,396 & 0,497 \\
Category & Medium & Medium \\
\hline
\end{tabular}

The assessment of the attitude of interest in scientific literacy based on the recapitulation of scientific literacy attitudes in the experimental class was taken from several components including the component of interest in science as many as 42 voices felt very interested, 33 voices felt quite interested and 3 voices felt less interested. Components rated the scientific approach to investigation as 62 voices felt very interested and 42 voices felt quite interested. 
And the environmental awareness component as many as 40 voices felt very interested and 12 felt quite interested.

This is due to the content knowledge is a material that includes the concept explanation so that the main concept is easier to understand. The knowledge content focusing in main concept understanding aspect in various forms of illustration exercises so that the science test completion requires accuracy in the completion.

Content knowledge from both samples has a significant ability because both are focused on understanding concepts which generally provide an initial overview of the material presented. These two classes follow a very thorough study of biology concepts to avoid misunderstanding the concepts.

The score on procedural knowledge has increased from the two sample classes where procedural knowledge is knowledge that focuses on the application or how to do something because procedural knowledge takes the form of a series of steps as a whole as a procedure. In the implementation of questions that take the form of steps that require cooperation and ideas from each group, automatically the ideas are channelled to be presented as an answer because the illustration or picture is a phenomenon that occurs in everyday life.

Epistemic knowledge is an explanation of ideas that are essential to the formation of the knowledge process in proving the truth of knowledge produced by science. The results obtained on content and procedural knowledge are inversely proportional to epistemic knowledge which shows the increase in scores is not too high, namely in the medium category. This happens because students are asked to make observations, learn to make hypotheses and can provide relevant evidence for scientific statements. The importance of content and procedural understanding of the context presented to help mastery of epistemic knowledge because they are continuous with each other. The low epistemic knowledge is also due to the lack of students getting experience in scientifically explaining phenomena, designing discoveries and evaluating discoveries that require the ability to interpret scientific data and evidence. The factors causing the low mastery of students in carrying out scientific investigation activities are: (1) Students rarely do practical activities; (2) Students do not understand the terms in some scientific investigation activities such as independent variables and dependent variables; (3) Learners spend more time with science that promotes memorization (Sukowati \& Rusilowati, 2017).

The attitude assessment is carried out as a measure and reference for the literacy attitude possessed by students from the statements submitted, it can be seen that students feel interested in mushroom material and scientific literacy questions. This happens because the material presented is related to everyday life. The process aspect consists of identifying scientific questions to explain scientific phenomena and using scientific evidence and assessment of attitudes or scientific values referring to responses to scientific issues with interest, support and responsibility (Windyarani \& Sutisnawati, 2016). The science learning process emphasizes more on abstract conceptualization and the lack of development on active experimentation and the importance of retraining students' abilities to scientific abilities.

Science literacy skills in the experimental class and control class both have increased. After learning in the experimental class using the CSCL (Computer-Supported Collaborative Learning) model by using a scientific literacy test which includes three indicators, namely content knowledge, procedural knowledge and epistemic knowledge. The score for both has a relatively high value, this is because the question of content knowledge is material that includes an explanation of concepts so that the main concepts are easy to understand. Content knowledge that focuses on aspects of understanding the main concepts is presented in several forms of illustration and picture questions so that the completion of the scientific literacy test requires accuracy in its completion. The content knowledge factor can be obtained a higher value compared to other knowledge because, in the use of the CSCL model students are able 
to utilize technology as a source of information and gain new knowledge independently related to answers or problem solving that require extensive evidence accompanied by logical and supported facts. The new learning atmosphere is not disturbed by other classes so that learning activities are more conducive. Content knowledge from both samples has a significant ability because both are focused on understanding concepts which generally provide an initial overview of the material presented. These two classes follow a very thorough study of biology concepts to avoid misunderstanding the concepts.

The score on procedural knowledge has increased from the two sample classes where procedural knowledge is knowledge that focuses on the application or how to do something because procedural knowledge takes the form of a series of steps as a whole as a procedure. In the implementation of questions that take the form of steps that require cooperation and ideas from each group, automatically the ideas are channelled to be presented as an answer because the illustration or picture is a phenomenon that occurs in everyday life. Based on the experience that is felt and seen, it becomes an idea that can be poured and communicated. Science literacy skills in the experimental class and control class both have increased. After learning in the experimental class using the CSCL (Computer-Supported Collaborative Learning) model by using a scientific literacy test which includes three indicators, namely content knowledge, procedural knowledge and epistemic knowledge. The score for both has a relatively high value, this is because the question of content knowledge is material that includes an explanation of concepts so that the main concepts are easy to understand. Content knowledge that focuses on aspects of understanding the main concepts is presented in several forms of illustration and picture questions so that the completion of the scientific literacy test requires accuracy in its completion. The content knowledge factor can be obtained a higher value compared to other knowledge because, in the use of the CSCL model students are able to utilize technology as a source of information and gain new knowledge independently related to answers or problem solving that require extensive evidence accompanied by logical and supported facts. by the new learning atmosphere is not disturbed by other classes so that learning activities are more conducive. Content knowledge from both samples has a significant ability because both are focused on understanding concepts which generally provide an initial overview of the material presented. These two classes follow a very thorough study of biology concepts to avoid misunderstanding the concepts.

The score on procedural knowledge has increased from the two sample classes where procedural knowledge is knowledge that focuses on the application or how to do something because procedural knowledge takes the form of a series of steps as a whole as a procedure. In the implementation of questions that take the form of steps that require cooperation and ideas from each group, automatically the ideas are channelled to be presented as an answer because the illustration or picture is a phenomenon that occurs in everyday life. Based on the experience that is felt and seen, it becomes an idea that can be poured and communicated.

Each indicator of scientific literacy is a continuous unit in solving scientific literacy test questions so that it is important to apply understanding concepts, scientific procedures and also proving the truth of science so that the emphasis on critical thinking and being able to make scientific decisions must be owned by students. This is evidenced by the acquisition of experimental class scores that experienced a relatively high increase in the treatment of the CSCL model which was superior to the conventional learning model.

The score of both classes has increased this is because epistemic knowledge is an explanation of ideas that are essential to the formation of the knowledge process in proving the truth of knowledge produced by science. The results obtained on content and procedural knowledge are inversely proportional to epistemic knowledge which shows the increase in scores is not too high, namely in the medium category. This happens because students are asked to make observations, learn to make hypotheses and can provide relevant evidence for 
scientific statements. The importance of content and procedural understanding of the context presented to help mastery of epistemic knowledge because they are continuous with each other. The low epistemic knowledge is also due to the lack of students getting experience in scientifically explaining phenomena, designing discoveries and evaluating discoveries that require the ability to interpret scientific data and evidence.

\section{Conclusion}

Based on the results of the study, there were differences in the scientific literacy abilities of students in the experimental class and the control class from the three indicators. In content and procedural knowledge, both classes got good results because of understanding the main concepts and the application of scientific steps, while in epistemic knowledge there was an increase but not high because there had never been implementation and learning related to observation. Learning outside the classroom provides a new atmosphere and enthusiasm and helps in influencing the concentration of students.

\section{Acknowledgement}

The authors would like to express great gratitude to the Head of Pondok Modern Assalam Sukabumi who has given their trust during the research and to the Head of Madrasah Aliyah Assalam Darul Faizah Sukabumi who has assisted in carrying out the research.

\section{References}

Adawiyah,R.,\&Wisudawati,A. W. (2017). Pengembangan Instrumen Tes Berbasis Literasi Sains: Menilai Pemahaman Fenomena Ilmiah Mengenai Energi. 10.

Allaymoun, M. H. (2018). CSCL Chats Analysis and Scientific Threads Discovery. 2018 8th International Conference on Computer Science and Information Technology (CSIT), 6265. https:// doi.org/10.1109/CSIT.2018.8486197

Dascalu, M., McNamara, D. S., Trausan-Matu, S., \& Allen, L. K. (2018). Cohesion network analysis of CSCL participation. Behavior Research Methods,50(2),604-619. https://doi.org/10.3758/s13428-017-0888-4

Haerani, S. A. S., Setiadi, D., \& Rasmi, D. A. C. (2020). Pengaruh Model Inkuiri Bebas Terhadap Kemampuan Literasi Sains. Jurnal Pijar Mipa, 15(2),140. https://doi.org/10.29303/jpm.v15i2.1682

Hasasiyah, S. H., Hutomo, B. A., Subali, B., \& Marwoto, P. (2019). Analisis Kemampuan Literasi Sains Siswa SMP pada Materi Sirkulasi Darah. Jurnal Penelitian Pendidikan IPA, 6(1), 5. https:/ / doi.org/10.29303/jppipa.v6i1.193

Muhammad, S. N., \& Adhani, A. (2018). Kemampuan Literasi Sains Siswa Pada Materi Ekosistem Di SMA Negeri 3 Tarakan Kalimantan Utara. 6.

Naila, I., \& Khasna, F. T. (2021). Pengaruh Pembelajaran Daring Terhadap Kemampuan Literasi Sains Calon Guru Sekolah Dasar: Sebuah Studi Pendahuluan. 7(1), 6.

Narut, Y. F., \& Supardi, K. (2019). Literasi Sains Peserta Didik Dalam Pembelajaran Ipa Di Indonesia. 9.

Ngalimun. (2017). Pembelajaran Terpadu. Parama Ilmu. 
Nofiana, M. (2017). Profil Kemampuan Literasi Sains Siswa SMP di Kota Purwokerto Ditinjau dari Aspek Konten, Proses, dan Konteks Sains. JSSH (Jurnal Sains Sosial dan Humaniora), 1(2), 77. https:// doi.org/10.30595/jssh.v1i2.1682

Nofiana, M., \& Julianto, Teguh. (2017). Profil Kemampuan Literasi Sains Siswa SMP di Kota Purwokerto Ditinjau dari Aspek Konten, Proses, dan Konteks Sains. JSSH (Jurnal Sains Sosial dan Humaniora),1(2),77. https:// doi.org/10.30595/jssh.v1i2.1682

Nugraheni, N. C., Paidi, D., \& Si, M. (n.d.). Kemampuan Literasi Sains Kelas X Sma Negeri Mata Pelajaran Biologi Berdasarkan Topografi Wilayah Gunungkidul. 2019, 11.

Pertiwi, U. D., Atanti, R. D., \& Ismawati, R. (2018). Pentingnya Literasi Sains Pada Pembelajaran Ipa Smp Abad 21. Indonesian Journal of Natural Science Education (IJNSE), 1(1), 24-29. https:/ / doi.org/10.31002/nse.v1i1.173

Pratiwi, S. N., Cari, C., \& Aminah, N. S. (2019). Pembelajaran IPA Abad 21 dengan Literasi Sains Siswa. 9, 9.

Rahayu, S. (2017). Mengoptimalkan Aspek Litaerasi dalam Pembelajaran Kimia Abad-21. 16.

Redhana, I. W. (2019). Mengembangkan Keterampilan Abad-21 dalam Pembelajaran Kimia. 13(1), 15.

Rini, C. P., Dwi Hartantri, S., \& Amaliyah, A. (2021). Analisis Kemampuan Literasi Sains Pada Aspek Kompetensi Mahasiswa PGSD FKIP Universitas Muhammadiyah Tangerang. $\begin{array}{llll}\text { Jurnal Pendidikan } \quad \text { Dasar } \quad \text { Nusantara, } & \text { 6(2), }\end{array}$ https://doi.org/10.29407/jpdn.v6i2.15320

Setiawan, A. R. (2019). Efektivitas Pembelajaran Biologi Berorientasi Literasi Saintifik. 12.

Situmorang, R. P. (2016). Integrasi Literasi Sains Peserta Didik Dalam Pembelajaran Sains. Satya Widya, 32(1), 49. https:// doi.org/10.24246/j.sw.2016.v32.i1.p49-56

Sukowati, D., \& Rusilowati, A. (2017). Analisis kemampuan literasi sains dan metakogntif peserta didik. 7.

Syofrianisda, M. S. (2019). Belajar Dan Pembelajaran (1st ed.). Parama Ilmu.

Windyariani, S., \& Sutisnawati, A. (2016). Pengembangan Asesmen Literasi Sains Berbasis Konteks Bagi Siswa Sekolah Dasar. 10.

Wulandari, N., \& Solihin, hayat. (2016). Analisis Kemampuan Literasi Sains Pada Aspek Pengetahuan Dan Kompetensi Sains Siswa Smp Pada Materi Kalor. Edusains, 8(1), 6673. https:// doi.org/10.15408/es.v8i1.1762

Wulandari, N., \& Wulandari, N. (2016). Analisis Kemampuan Literasi Sains Pada Aspek Pengetahuan Dan Kompetensi Sains Siswa SMP Pada Materi Kalor. EDUSAINS, 8(1), 66-73. https://doi.org/10.15408/es.v8i1.1762

Yuliati, Y. (2017). Literasi Sains Dalam Pembelajaran Ipa. Jurnal Cakrawala Pendas, 3(2). https:// doi.org/10.31949/jcp.v3i2.592

Zakaria, M. R., \& Rosdiana, L. (2018). Profil Literasi Sains Peserta Didik Kelas VII Pada Topik Pemanasan. 06, 5. 